Title Page

\title{
Down-Regulation of the Placental BCRP/ABCG2 Transporter in Response to Hypoxia Signaling
}

\begin{abstract}
Lissa N. Francois ${ }^{\mathrm{a}}$, Ludwik Gorczyca ${ }^{\mathrm{b}}$, Jianyao Du$^{\mathrm{c}}$, Kristin M. Bircsak ${ }^{\mathrm{b}}$, Elizabeth Yen ${ }^{\mathrm{d}}$, Xia Wen ${ }^{\mathrm{b}}$, Mei-Juan Tu ${ }^{\mathrm{e}}$, Ai-Ming Yu ${ }^{\mathrm{e}}$, Nicholas P. Illsley ${ }^{\mathrm{f}}$, Stacy Zamudio ${ }^{\mathrm{f}}$, Lauren M. Aleksunes ${ }^{\mathrm{b}, \mathrm{g}}$
\end{abstract}

\author{
Affiliations: \\ ${ }^{a}$ Rutgers University, Robert Wood Johnson Medical School, Department of Obstetrics, Gynecology and \\ Reproductive Sciences, Maternal-Fetal Medicine Division, 125 Paterson St. New Brunswick, NJ 08091, \\ USA \\ ${ }^{\mathrm{b}}$ Rutgers University, Ernest Mario School of Pharmacy, Department of Pharmacology and Toxicology, \\ 170 Frelinghuysen Rd. Piscataway, NJ 08854, USA \\ ${ }^{c}$ China Pharmaceutical University, Gulou, Nanjing, Jiangsu, China \\ ${ }^{\mathrm{d}}$ Rutgers University, Robert Wood Johnson Medical School, Department of Pediatrics, Division of \\ Neonatology, 1 Robert Wood Johnson Place. New Brunswick, NJ 08903, USA \\ ${ }^{\mathrm{e}}$ University of California, Davis, Department of Biochemistry and Molecular Medicine, 2700 Stockton \\ Blvd. Sacramento, CA 95817, USA \\ ${ }^{\mathrm{f}}$ Hackensack University Medical Center, Department of Obstetrics and Gynecology, 30 Prospect Ave. \\ Hackensack, NJ 07601, USA \\ ${ }^{\mathrm{g}}$ Environmental and Occupational Health Sciences Institute, 170 Frelinghuysen Rd., Piscataway, NJ \\ 08854, USA
}

Send Correspondence to: Lauren Aleksunes, Pharm.D., Ph.D., D.A.B.T., Dept. of Pharmacology and Toxicology, Rutgers University, 170 Frelinghuysen Road. Piscataway, NJ 08854 USA Phone: 848-4455518, Fax: 732-445-0119 E-mail: aleksunes@eohsi.rutgers.edu 


\begin{abstract}
Introduction: The BCRP/ABCG2 efflux transporter protects the developing fetus by limiting the transplacental transfer of drugs and chemicals and prevents the apoptosis of trophoblasts. The purpose of this study was to determine whether hypoxia-related signaling alters placental BCRP expression and function in vitro and in human pregnancies.
\end{abstract}

Methods: Human BeWo choriocarcinoma cells were treated with the hypoxia mimetic, cobalt chloride $\left(\mathrm{CoCl}_{2}\right)$, or $3 \%$ oxygen for $24-48 \mathrm{~h}$. Activation of HIF-1 $\alpha$ signaling and regulation of BCRP was assessed using qPCR, ELISA, western blotting and a fluorescent substrate transport assay. In addition, healthy term placentas from high altitude pregnancies with chronic hypoxia were assessed for BCRP expression.

Results: $\mathrm{CoCl}_{2}$ and 3\% oxygen increased HIF-1 $\alpha$ protein signaling and decreased the mRNA and protein expression of BCRP by 30-75\% in BeWo cells. Reduced BCRP expression corresponded with impaired efflux activity during hypoxia as evidenced by accumulation of the substrate Hoechst 33342. A number of transcription factors known to regulate BCRP, including AHR, NRF2 and PPAR $\gamma$, were also coordinately down-regulated by 3\% oxygen in BeWo cells. Moreover, women who gave birth at a high altitude (3100 m) exhibited signs of chronic placental hypoxia, including enhanced protein expression of the HIF-1 $\alpha$ target GLUT1, and had reduced BCRP levels in microvillous membranes compared to women at a moderate altitude $(1600 \mathrm{~m})$.

Discussion: This study provides novel insight into the regulation of the placental BCRP transporter by hypoxia, which may be important for exposure of the fetus to chemicals during early development and in hypoxia-related pregnancy disorders.

Keywords: BCRP, ABCG2, placenta, transporter, hypoxia 
2 The breast cancer resistance protein (BCRP/ABCG2) is an efflux transporter that is highly expressed on

3 the apical membrane of placenta syncytiotrophoblasts and fetal endothelial cells $[1,2]$. BCRP actively

4 transports xenobiotics and endogenous chemicals away from the fetus and into the maternal circulation

5 [3]. BCRP substrates include many compounds that may be relevant during pregnancy such as the

6 gestational diabetes drug glyburide, the antibiotic nitrofurantoin, the acid reflux medication cimetidine,

7 and the dietary phytoestrogen genistein [4-7]. Mouse fetuses lacking Bcrp expression in the placenta

8 exhibit elevated concentrations of glyburide, nitrofurantoin, and genistein [4-7]. In addition to serving as

9 a key component of the blood-placental barrier, BCRP critically prevents cytokine-induced apoptosis and

10 enhances syncytial formation in placental cells $[12,13]$. Reductions in BCRP expression lead to greater

11 cytokine-induced damage and lower expression of human chorionic gonadotropin beta and syncytin-1

$12[12,13]$. Due to the important role of BCRP in maintaining placental health and protecting the fetus from

13 xenobiotic exposure, it is critical to understand factors and conditions that may compromise its function.

15 While the placental environment is maintained under low oxygen tension relative to the maternal 16 circulation throughout gestation the influence of hypoxia on placental BCRP expression remains unclear.

17 Importantly, oxygen tension is quite low in the first trimester and increases during the $2^{\text {nd }}$ and $3^{\text {rd }}$ 18 trimesters $\left(1^{\text {st }}\right.$ trimester: $2-3 \% \mathrm{O}_{2}, \sim 20 \mathrm{mmHg} ; 2^{\text {nd }}$ trimester: $8-10 \% \mathrm{O}_{2}, \sim 60 \mathrm{mmHg}, 3^{\text {rd }}$ trimester $40-60$

$19 \mathrm{mmHg}, 5-8 \% \mathrm{O}_{2}$ ) [8]. A previous study has demonstrated an up-regulation of Bcrp protein expression in 20 mouse hematopoietic stem cells under hypoxic conditions following direct transactivation by the hypoxia 21 inducible factor-1 alpha (Hif-1 $\alpha$ ) transcription factor [9]. Furthermore, a direct relationship between Hif$221 \alpha$ and Bcrp mRNA levels has been reported in mouse placentas [10]. However, more recent evidence 23 suggests that hypoxia may have the opposite effect in the human placenta. In fact, expression of BCRP 24 mRNA was shown to be directly related to oxygen levels in human $1^{\text {st }}$ trimester placental explants, such 25 that lower $B C R P$ expression was observed in explants exposed to $3 \% \mathrm{O}_{2}$ as compared to greater 
expression at $20 \% \mathrm{O}_{2}$ [11]. These divergent results suggest that additional mediators may be involved in

27 the regulation of BCRP in the human placenta during hypoxia.

In addition to HIF-1 $\alpha$, a number of transcription factors have been shown to directly bind to the promoter and transactivate the $A B C G 2$ gene that encodes the BCRP protein leading to increased mRNA expression.

31 Of these factors, those expressed in placenta include the aryl hydrocarbon receptor (AHR) [12, 13], 32 estrogen receptor- $\alpha(\mathrm{ER} \alpha)$ [14, 15], nuclear factor (erythroid-derived 2)-like 2 (NRF2) [16, 17], 33 peroxisome proliferator-activated receptors (PPAR) $[18,19]$, and retinoid X receptor- $\alpha(\mathrm{RXR} \alpha)$. More

34 recent studies into the dynamic mechanisms regulating BCRP mRNA have demonstrated that levels can 35 also be inversely related to the expression of certain miRNAs, including miR-519c, miR-520h, and miR-

36328 , that target the $A B C G 2$ gene [20, 21]. Specifically, methylation of the miR-328 5'-flanking region

37 correlated negatively with miR-328 levels and positively with BCRP mRNA expression in human

38 placentas [22]. These pathways provide potential mechanisms by which hypoxia could alter BCRP 39 expression.

41 There are a number of experimental approaches to study hypoxia-related signaling. For example, the 42 hypoxia mimetic cobalt chloride $\left(\mathrm{CoCl}_{2}\right)$ has been shown to prevent the breakdown of HIF-1 $\alpha$ protein and 43 enhance the expression of target genes such as the glucose transporter 1 (GLUT1) in placental 44 choriocarcinoma BeWo cells $[23,24]$. Similar to $\mathrm{CoCl}_{2}$, exposure of BeWo cells to $1-5 \% \mathrm{O}_{2}$ increases 45 expression of GLUT1 protein [24]. Analogous results have been observed in vivo from placentas obtained 46 from healthy pregnant women at different elevations. Interestingly, placentas from women living at high 47 altitudes (3100m in Colorado) exhibited higher HIF-1 $\alpha$ protein expression and the neonates had reduced 48 birth weights compared to those at moderate altitudes (1600m in Colorado) [25]. Across both altitudes 49 HIF-1 $\alpha$ protein levels were strongly, negatively associated with the placental:birth weight ratio, indicating 50 that greater HIF-1 $\alpha$ stimulation is related to lower placental efficiency, i.e. a larger placenta is required to 51 sustain a certain level of fetal growth where HIF-1 $\alpha$ levels are elevated. 
53 Using complementary models of placental hypoxia, the purpose of this study was to 1) characterize the 54 effect of HIF-1 $\alpha$ activation on BCRP expression and function in human placental BeWo cells, 2) identify 55 potential regulatory factors controlling BCRP expression during hypoxia, and 3) quantify BCRP protein 56 expression during chronic hypoxia using maternal-facing microvillus membranes from healthy, term 57 human placentas from high altitude pregnancies. 
Materials and Methods

59 Chemicals. All chemicals were obtained from Sigma-Aldrich (St. Louis, MO) unless otherwise specified.

61 BeWo cell culture. The BeWo choriocarcinoma cell line was maintained in DMEM: F-12 containing

$6210 \%$ fetal bovine serum (Atlanta Biologicals, Flowery Branch, GA) and 1\% penicillin-streptomycin at $63 \quad 37^{\circ} \mathrm{C}$ and $5 \% \mathrm{CO}_{2}$ (atmospheric $\mathrm{O}_{2}, \sim 20 \%$ ). $\mathrm{CoCl}_{2}$ Studies. BeWo cells were cultured in DMEM:F-12

64 with $0.5 \%$ bovine serum albumin, $5 \mathrm{mM}$ glucose and $1 \%$ penicillin-streptomycin $24 \mathrm{~h}$ prior to $\mathrm{CoCl}_{2}$

65 treatment [24]. Cells were then treated with $\mathrm{CoCl}_{2}(200 \mu \mathrm{M})$ for 24 to 48 h. Hypoxia Chamber Studies.

66 BeWo cells in normal culture media were placed in the Modular Incubator Chamber (MIC-101) (Billups-

67 Rothenberg, Inc, Del Mar, CA) and gas $\left(3 \% \mathrm{O}_{2}, 5 \% \mathrm{CO}_{2}\right)$ was flushed through the chamber at a regulated

68 flow rate of 25-50 liters/min for $6 \mathrm{~min}$ in order to obtain a 100\% exchange of gases. After flushing was

69 completed, the chamber was placed into the cell culture incubator at $37^{\circ} \mathrm{C}$ for $24 \mathrm{~h}$. A separate set of

70 BeWo cells were placed into the same cell culture incubator and incubated for $24 \mathrm{~h}$ under standard culture

71 conditions $\left(37^{\circ} \mathrm{C}, 20 \% \mathrm{O}_{2}, 5 \% \mathrm{CO}_{2}\right)$.

73 Placental microvillous membranes. Placenta microvillous membranes were prepared from frozen tissue

74 as described [26]. The high altitude samples (3100 m, Leadville, CO) were previously characterized for 75 markers of hypoxia compared to the moderate altitude samples (1600 m, Denver, CO) [26]. The current 76 study was approved by the Rutgers Institutional Review Board (exempt protocol E15-729). Subjects 77 included $n=8$ from the moderate altitude ( $n=2$ male, $n=6$ female) and $n=7$ from the high altitude ( $n=2$ 78 male, $\mathrm{n}=5$ female). The race of all mothers was Caucasian. The race of fathers was Caucasian with two 79 fathers in the high altitude group who identified their ethnicity as Hispanic. Both groups were similar with

80 regards to maternal age (range 18-36 y, $p=0.783$ ), pre-pregnancy BMI (range 19.4-25.7, $p=0.530$ ), weight 81 gain during pregnancy (range 8.2-24 kg, $p=0.624$ ), and gestational age at delivery (range 37.1-41.1 82 weeks, $p=0.797)$. 
84 Alamar Blue Assay. BeWo cell viability was assessed using the Alamar Blue Assay (Life Technologies)

85 with fluorescence detection using a Spectramax M5 plate reader (Molecular Devices, Sunnyvale, CA).

HIF-1 $\alpha$ ELISA. The HIF-1alpha Human SimpleStep ELISA Kit (Abcam, Cambridge, MA) was used.

RNA isolation and real-time quantitative PCR. RNA was isolated and qPCR performed as previously described [27]. Stem-loop reverse transcription real-time qPCR for microRNA (miRNA) was performed

91 using the primers and methods as reported [20]. Primer sequences are listed in Supplemental Table 1.

92 Cycle threshold $(\mathrm{Ct})$ values were first converted to delta $\mathrm{Ct}$ values by comparing to the reference genes,

93 RPL13A (for mRNA) and U6 (for miRNA) and then to delta delta Ct values by comparing to the 94 respective control-treated cells [28].

Western blot analysis. Proteins from cell homogenates $(10 \mu \mathrm{g})$ or placental microvillous membranes $(15 \mu \mathrm{g})$ were separated on SDS-polyacrylamide 4-12\% Bis-Tris gels (Life Technologies) by electrophoresis [27]. The following antibodies were used: BCRP (BXP-53 Enzo LifeSciences, Farmingdale, NY, 1:5000), GLUT1 (Ab652 Abcam, Cambridge, MA, 1:1000) and $\beta$-ACTIN (Ab8227 Abcam, 1:2000). BCRP and GLUT1 protein levels in BeWo cells were normalized to $\beta$-Actin levels. Due to changes in protein loading controls in the high altitude placentas, raw luminescence values for BCRP and GLUT1 staining were presented after confirming equal protein loading with Coomassie blue dye.

104 Hoechst 33342 retention assay. Transporter function was quantified using a Nexcelom Cellometer 105 fluorescent cell counter (Lawrence, MA) and the fluorescent substrate Hoechst $33342(5 \mu \mathrm{M})$ as 106 previously described [29].

107

108 Statistical Analysis. Data are expressed as mean \pm SE and analyzed using Graphpad Prism 6.0 109 (GraphPad Software, Inc., La Jolla, CA). One-way ANOVA followed by a Newman-Keuls multiple 
110 comparison post hoc test was used when comparing 3 or more groups, while an unpaired Student's t-test

111 was used when comparing 2 groups. Statistical significance was set at $\mathrm{p}<0.05$. 


\section{Results}

113 Regulation of HIF-1 $\alpha$ signaling and BCRP expression by the hypoxia mimetic $\mathrm{CoCl}_{2}$ in $\mathrm{BeWo}$ cells.

114 Treatment of BeWo cells with $\mathrm{CoCl}_{2}(200 \mu \mathrm{M})$ increased total cellular HIF-1 $\alpha$ protein at $24 \mathrm{~h}$ (4-fold)

115 (Fig. 1A) compared to control cells. Prototypical HIF-1 $\alpha$ target genes, VEGF and GLUT1, as well as

116 GLUT1 protein were also induced by $\mathrm{CoCl}_{2}$ at $48 \mathrm{~h}$ (Fig. $1 \mathrm{~B}$ and $1 \mathrm{C}$ ). Conversely, $\mathrm{CoCl}_{2}$ treatment

117 reduced BCRP mRNA and protein expression at $48 \mathrm{~h}$ to $25 \%$ and $70 \%$ of control levels, respectively (Fig.

$1182 \mathrm{~A}$ and $\mathrm{B})$. Reduced BCRP protein expression in BeWo cells corresponded with impaired transport

119 activity as evidenced by a 2 -fold increase in the cellular retention of the fluorescent BCRP substrate,

120 Hoechst 33342 (Fig. 2C). The BCRP inhibitor Ko143 (1 $\mu \mathrm{M})$ was used as a positive control and increased

121 Hoechst 33342 retention 3 -fold. It should be noted that the concentration of $\mathrm{CoCl}_{2}$ used in these studies

122 did not alter cell viability at $48 \mathrm{~h}$ as determined by the Alamar Blue Assay (data not shown).

124 Regulation of HIF-1 $\alpha$ signaling and BCRP expression by low oxygen content $\left(3 \% \mathbf{O}_{2}\right)$ in $\mathbf{B e W o}$

125 cells. Compared to standard culture conditions $\left(20 \% \mathrm{O}_{2}\right)$, exposure of BeWo cells to low oxygen levels

$126\left(3 \% \mathrm{O}_{2}\right)$ for $24 \mathrm{~h}$ increased HIF-1 $\alpha$ protein levels by $50 \%$ (Fig. 3A). Corresponding increases in VEGF

127 and GLUT1 mRNAs (2- and 4-fold, respectively) as well as GLUT1 protein were observed in cells

128 exposed to $3 \% \mathrm{O}_{2}$ (Fig. 3B and 3C). Low oxygen levels $\left(3 \% \mathrm{O}_{2}, 24 \mathrm{~h}\right.$ ) down-regulated BCRP mRNA and

129 protein by $60 \%$ and $40 \%$, respectively (Figs. 4A and B). Consequently, BCRP function was reduced by

$1303 \% \mathrm{O}_{2}$ as demonstrated by a 2-fold increase in the cellular retention of Hoechst 33342 (Fig. 4C).

131

132 To elucidate a potential mechanism for the reduction of BCRP expression following activation of the 133 HIF-1 $\alpha$ pathway, we quantified the expression of critical miRNAs and transcription factors. All three 134 BCRP regulatory miRNAs were reduced by 25 to $30 \%$ in response to hypoxia (Fig. 5A) suggesting that 135 they were not responsible for the decrease in BCRP expression. By comparison, exposure of BeWo cells 136 to $3 \% \mathrm{O}_{2}$ for $24 \mathrm{~h}$ significantly lowered the mRNA expression of AHR, NRF2, PPAR $\gamma$ and RXR $\alpha$ 
137 between 20-60\% (Fig. 5B). Meanwhile, there was a trend for a 3-fold induction of ER $\alpha$ mRNA in 138 response to $3 \% \mathrm{O}_{2}$ (Fig. 5B).

140 Regulation of GLUT1 and BCRP expression in placentas from a high altitude. Placentas were 141 obtained from women at moderate $(1600 \mathrm{~m}, \mathrm{n}=8)$ and high altitudes $(3100 \mathrm{~m}, \mathrm{n}=7)$ as previously described 142 [26]. Placentas from the $3100 \mathrm{~m}$ altitude exhibited greater weights compared to the moderate altitude 143 placentas (Fig. 6A) and infants born at the higher altitude tended to have reduced birth weights similar to 144 published findings [26]. Western blot analysis of microvillous membranes revealed that placentas from a 145 high altitude $(3100 \mathrm{~m})$ exhibited 30\% higher GLUT1 protein expression than moderate altitude (1600 m) 146 placentas (Fig. 6B). Additionally, BCRP protein expression was reduced by approximately $20 \%$ in high 147 altitude $(3100 \mathrm{~m})$ placentas as compared to those from a moderate altitude (1600 m). 


\section{Discussion}

149 The current study characterized the influence of hypoxic conditions on placental BCRP expression and

150 function. Treatment of BeWo cells with $\mathrm{CoCl}_{2}$ or $3 \% \mathrm{O}_{2}$ activated the HIF-1 $\alpha$ transcription factor

151 pathway, while reducing BCRP expression and function. Altered expression of known transcription

152 factors following $3 \% \mathrm{O}_{2}$ exposure, likely underlie the hypoxia-mediated down-regulation of BCRP in

153 placental cells. Finally, microvillous membranes isolated from term placentas of high altitude pregnancies

154 (3100 m), exhibited reduced levels of BCRP concurrently with the up-regulation of the HIF-1 $\alpha$ target,

155 GLUT1. Our data shed light on the regulation of the human placental BCRP transporter by hypoxia,

156 which may be important in hypoxia-related pathologies of pregnancy such as preeclampsia and growth

157 restriction.

159 Proper human placental development is dependent upon tightly-regulated oxygen concentrations [30, 31].

160 Through the $1^{\text {st }}$ trimester, placental invasion occurs at a low oxygen tension $\left(\sim 20 \mathrm{mmHg}, 2-3 \% \mathrm{O}_{2}\right)$ as the 161 uterine spiral arterioles are plugged by extravillous trophoblasts. During this period, the HIF-1 $\alpha$ protein is 162 preferentially located in villous cytotrophoblasts, as syncytiotrophoblasts contain the von Hippel-Lindau 163 tumor suppressor protein, which ubiquitinates HIF-1 $\alpha$ and targets it for proteasomal degradation [32]. By 164 weeks 10 to 12 , maternal blood flow to the placenta is established, thereby increasing the placental 165 oxygen tension $\left(\sim 55 \mathrm{mmHg}, 8 \%\right.$ to $\left.10 \% \mathrm{O}_{2}\right)$. Immunohistochemical analysis suggests that BCRP 166 staining is less intense in cytotrophoblasts and syncytiotrophoblasts from $1^{\text {st }}$ trimester placentas than in 167 term placentas [11]. Western blot analysis has also revealed lower BCRP protein expression earlier in 168 pregnancy compared to term in whole tissue homogenates [33]. Others have reported variable BCRP 169 expression between placentas that precluded analysis of gestational age-related changes [34].

170 Nonetheless, these data generally support a trend for lower BCRP protein levels early in gestation when

171 oxygen levels are low which is consistent with our observations that activation of HIF-1 $\alpha$ is inversely 172 related to the expression of BCRP in placental cells. 
174 More recent work has begun to address the ability of hypoxia to regulate BCRP expression in placental 175 explants. Exposure of $1^{\text {st }}$ trimester explants to varying levels of $\mathrm{O}_{2}\left(3,8\right.$ and 20\%) revealed that higher $\mathrm{O}_{2}$ 176 tension was associated with greater BCRP mRNA expression [11]. These data are consistent with the 177 findings in the current study. However, immunohistochemical analysis demonstrated BCRP protein 178 expression to be up-regulated in $1^{\text {st }}$ trimester explants at low $\mathrm{O}_{2}$ levels [11]. The disconnect between the 179 mRNA and protein findings in this prior study were not clear and may represent an acute stress of 180 explants to the substantial change in oxygen concentrations. Time-dependent differences in acute and 181 chronic responses to hypoxia have been demonstrated previously, operating through distinct signaling 182 pathways [35]. Using term placental explants, the same laboratory demonstrated that low $\mathrm{O}_{2}$ 183 concentrations (3\%) had no effect on BCRP mRNA or protein expression, suggesting that responses to 184 hypoxia are dependent upon the stage of placental development [36].

186 In the present studies, the down-regulation of BCRP in the placenta by hypoxia was somewhat surprising 187 since investigations in other cell types and tissues demonstrated that HIF-1 $\alpha$ can directly transactivate the 188 human $A B C G 2$ gene at specific response elements (-1059 to $-1055 \mathrm{bp},-194$ bp to $-190 \mathrm{bp}$, and -116 to $189112 \mathrm{bp})[9,37]$. Because of this disconnect, we explored the expression of transcriptional and epigenetic 190 pathways that could explain BCRP down-regulation in placental cells during hypoxia. We anticipated the 191 up-regulation of miR-328, $-519 \mathrm{c}$, and $-520 \mathrm{~h}$, which could lead to BCRP mRNA; however, the opposite 192 was observed suggesting that altered miRNA regulation was an unlikely mechanism in the current study.

194 Transcription factors directly regulate BCRP expression through activation of response elements in the 195 promoter of the $A B C G 2$ gene. These factors include NRF2 [16, 17], AHR [12, 13], PPAR $[18,19]$, ER $\alpha$ $196[14,15]$, as well as $\operatorname{RXR} \alpha$, a common nuclear receptor partner for activated transcription factors. 197 Interestingly, the mRNA expression of these transcription factors, with the exception of ER $\alpha$, decreased 198 in response to $3 \% \mathrm{O}_{2}$ and provide candidate regulators that may underlie the down-regulation of BCRP 199 during hypoxia. Prior work by Wang et al. has demonstrated that mRNA levels of Bcrp in mouse 
placentas correlate with a number of transcription factors including HIF-1 $\alpha$, AhR and ER $\beta$ [10]. While

201 these data infer a relationship, the ability of some transcription factors such as HIF-1 $\alpha$ to regulate

202 expression of a transgene is dependent upon activation of the signaling pathway rather than the relative

203 abundance of mRNAs. Notably, when trophoectoderm cells were exposed to low oxygen conditions, HIF-

$2041 \alpha$ protein was increased but no change in mRNA expression was observed suggesting little dependence

205 upon transcriptional regulation [38]. Like Wang et al., we have observed a coordinated regulation of AHR

206 and BCRP mRNAs. Both genes declined in response to hypoxia in BeWo cells as well as explants

207 obtained from third trimester healthy placentas (data not shown). It is important to note that while Wang

208 et al. observed a correlation between AhR and Bcrp mRNAs in mice, prior work has shown that

209 pharmacological activation of AhR does not alter Abcg2 transcription in mice (including placenta)

210 whereas the human AHR receptor can transactivate the ABCG2 gene and increase expression [39].

211 Supporting AHR as a mediator of BCRP down-regulation, it is known that hypoxia reduces the

212 transcriptional activity of AHR $[40,41]$ in part due to competition for the common heterodimer partner,

213 aryl hydrocarbon receptor nuclear translocator [40]. Therefore, dysregulation of placental AHR signaling

214 by HIF-1 $\alpha$ activation is a likely mechanism for the decline in BCRP expression and function in BeWo

215 cells.

216

217 A number of gestational disorders that are complicated by low oxygen tension result in reduced placental

218 BCRP expression. For example, BCRP expression was reduced in placentas from preeclamptic

219 pregnancies that were accompanied by HELLP syndrome [42]. This finding corresponded with a

220 significant decrease in birth weight $(\sim 25 \%)$ in infants born to mothers with preeclampsia and HELLP.

221 Likewise, levels of BCRP mRNA were reduced $\sim 40 \%$ in placentas from pregnancies affected by fetal

222 growth restriction in the absence of preeclampsia compared to placentas from gestational age matched

223 controls [43]. The authors postulated that reduced BCRP expression in fetal growth restriction may

224 sensitize the placenta to increased apoptosis due to altered responses to cytokines. The general association

225 between reduced birth weight and lower BCRP expression was also observed in the current study 
226 investigating healthy placentas from high altitude that experience preplacental hypoxia in the absence of 227 pathological disease. Taken together, these findings suggest that activation of human HIF-1 $\alpha$ signaling 228 reduces placental BCRP expression in vitro and in vivo likely by dysregulating critical transcriptional 229 pathways, such as AHR. 
Fig. 1 Activation of HIF-1a signaling in BeWo cells by $\mathrm{CoCl}_{2}$. Following treatment of BeWo cells with

$234 \mathrm{CoCl}_{2}(200 \mu \mathrm{M})(\mathrm{A}) \mathrm{HIF}-1 \alpha$ protein levels were quantified by ELISA at $24 \mathrm{~h}$. (B) HIF-1 $\alpha$ target gene 235 (VEGF and GLUT1) expression was assessed at $48 \mathrm{~h}$ by qPCR and normalized to RPL13A. (C) GLUT1 236 protein expression was determined by western blot and $\beta$-ACTIN was used as a loading control. Data are 237 presented as mean \pm SE $(n=3-4)$. Asterisks $(*)$ represent statistically significant differences $(\mathrm{p}<0.05)$ 238 compared to control cells (Con).

Fig. 2 Down-regulation of BCRP in BeWo cells by $\mathbf{C o C l}_{2}$. BeWo cells were treated with $\mathrm{CoCl}_{2}(200$ $241 \mu \mathrm{M}$ ) for $48 \mathrm{~h}$, following which they were processed for (A) BCRP and RPL13A mRNA expression by 242 qPCR. (B) Protein expression of BCRP was determined by western blot and $\beta$-ACTIN was used as a 243 loading control. (C) BCRP function was assessed by measuring the cellular retention of Hoechst 33342 (5 $244 \mu \mathrm{M})$ in the presence or absence of the BCRP-specific inhibitor (1 $\mu \mathrm{M}$ Ko143). Intracellular fluorescence 245 was quantified by a Cellometer Vision automated cell counter. Data are presented as mean \pm SE $(n=3-4)$. Asterisks $(*)$ represent statistically significant differences $(\mathrm{p}<0.05)$ compared to control cells $($ Con $)$.

Fig. 3 Activation of HIF-1a signaling in BeWo cells by hypoxia. Following $24 \mathrm{~h}$ exposure of BeWo 249 cells to hypoxia $\left(3 \% \mathrm{O}_{2}\right)$, (A) HIF-1 $\alpha$ protein levels were quantified by ELISA. (B) HIF-1 $\alpha$ target gene 250 (VEGF and GLUT1) expression was assessed by qPCR and normalized to RPL13A. (C) GLUT1 protein 251 expression was determined by western blot and $\beta$-ACTIN was used as a loading control. Data are 252 presented as mean \pm SE $(n=3-4)$. Asterisks $(*)$ represent statistically significant differences $(\mathrm{p}<0.05)$ 253 compared to $20 \% \mathrm{O}_{2}$ cells.

255 Fig. 4 Down-regulation of BCRP in BeWo cells by hypoxia. BeWo cells were exposed to hypoxia (3\% $256 \mathrm{O}_{2}$ ) for $24 \mathrm{~h}$, following which the cells were processed for (A) BCRP and RPL13A mRNA expression by 
257 qPCR. (B) Protein expression of BCRP was determined by western blot and $\beta$-ACTIN was used as a 258 loading control. (C) BCRP function was assessed by measuring the cellular retention of Hoechst 33342 (5 $259 \mu \mathrm{M})$. Intracellular fluorescence was quantified by a Cellometer Vision automated cell counter. Data are 260 presented as mean \pm SE $(n=3-4)$. Asterisks $(*)$ represent statistically significant differences $(\mathrm{p}<0.05)$ 261 compared to $20 \% \mathrm{O}_{2}$ cells.

263 Fig. 5. Effect of hypoxia on BCRP-related miRNA and transcription factor mRNA expression in

264 BeWo cells. Following $24 \mathrm{~h}$ exposure of BeWo cells to hypoxia $\left(3 \% \mathrm{O}_{2}\right)$, (A) BCRP-targeted miRNA 265 (miR-328, -519c, and -520) expression and (B) mRNA expression of transcription factors (AhR, ER $\alpha$, 266 NRF2, PPAR $\gamma, \operatorname{RXR} \alpha$ ) was determined by qPCR. miRNAs were normalized to U6 and mRNAs were 267 normalized to RPL13A. Data are presented as mean \pm SE ( $n=3-5)$. Asterisks (*) represent statistically 268 significant differences $(\mathrm{p}<0.05)$ compared to $20 \% \mathrm{O}_{2}$ cells.

270 Fig. 6. Regulation of BCRP and GLUT1 expression in high altitude placentas. In microvillous 271 membranes isolated from placentas from women living at a moderate (Mod, $1600 \mathrm{~m}$ ) or high altitude 272 (3100 m), GLUT1 and BCRP protein expression was determined by western blot. Equal protein loading 273 was confirmed after staining western blots with Coomassie blue dye. Data are presented as mean \pm SE $274(\mathrm{n}=7-9)$ Asterisks $(*)$ represent statistically significant differences $(\mathrm{p}<0.05)$ compared to moderate 275 altitude samples (Mod). 


\section{Funding}

277 This work was supported by the National Institutes of Environmental Health Sciences [Grants ES020522, 278 ES005022, ES007148], a component of the National Institutes of Health. Kristin Bircsak was supported 279 by predoctoral fellowships from the American Foundation for Pharmaceutical Education and

280 Pharmaceutical Research and Manufacturers of America. High altitude studies were supported by the 281 National Science Foundation [Grant BCS 0309142 to S.Z.], and the National Institute of Child Health and

282 Human Development, a component of the National Institutes of Health [Grants HD042737 to S.Z. and 283 HD046982 to N.I.]. 


\section{References}

285 [1] R. Allikmets, L.M. Schriml, A. Hutchinson, V. Romano-Spica, M. Dean, A human placentaspecific ATP-binding cassette gene (ABCP) on chromosome 4q22 that is involved in multidrug resistance, Cancer Res 58(23) (1998) 5337-9.

[2] M. Maliepaard, G.L. Scheffer, I.F. Faneyte, M.A. van Gastelen, A.C. Pijnenborg, A.H. Schinkel, M.J. van De Vijver, R.J. Scheper, J.H. Schellens, Subcellular localization and distribution of the breast cancer resistance protein transporter in normal human tissues, Cancer Res 61(8) (2001) 3458-64.

[3] J.W. Jonker, M. Buitelaar, E. Wagenaar, M.A. Van Der Valk, G.L. Scheffer, R.J. Scheper, T. Plosch, F. Kuipers, R.P. Elferink, H. Rosing, J.H. Beijnen, A.H. Schinkel, The breast cancer resistance protein protects against a major chlorophyll-derived dietary phototoxin and protoporphyria, Proc Natl Acad Sci U S A 99(24) (2002) 15649-54.

[4] C. Gedeon, J. Behravan, G. Koren, M. Piquette-Miller, Transport of glyburide by placental ABC transporters: implications in fetal drug exposure, Placenta 27(11-12) (2006) 1096-102.

[5] G. Merino, J.W. Jonker, E. Wagenaar, A.E. van Herwaarden, A.H. Schinkel, The breast cancer resistance protein (BCRP/ABCG2) affects pharmacokinetics, hepatobiliary excretion, and milk secretion of the antibiotic nitrofurantoin, Molecular pharmacology 67(5) (2005) 1758-64.

[6] P. Pavek, G. Merino, E. Wagenaar, E. Bolscher, M. Novotna, J.W. Jonker, A.H. Schinkel, Human breast cancer resistance protein: interactions with steroid drugs, hormones, the dietary carcinogen 2-amino-1-methyl-6-phenylimidazo(4,5-b)pyridine, and transport of cimetidine, J

[8] F. Rodesch, P. Simon, C. Donner, E. Jauniaux, Oxygen measurements in endometrial and trophoblastic tissues during early pregnancy, Obstetrics and gynecology 80(2) (1992) 283-5.

[9] P. Krishnamurthy, D.D. Ross, T. Nakanishi, K. Bailey-Dell, S. Zhou, K.E. Mercer, B.

Sarkadi, B.P. Sorrentino, J.D. Schuetz, The stem cell marker Bcrp/ABCG2 enhances hypoxic cell survival through interactions with heme, J Biol Chem 279(23) (2004) 24218-25.

313 [10] H. Wang, X. Wu, K. Hudkins, A. Mikheev, H. Zhang, A. Gupta, J.D. Unadkat, Q. Mao, 314 Expression of the breast cancer resistance protein (Bcrp1/Abcg2) in tissues from pregnant mice: 315 effects of pregnancy and correlations with nuclear receptors, American journal of physiology. 316 Endocrinology and metabolism 291(6) (2006) E1295-304.

317 [11] P. Lye, E. Bloise, C. Dunk, M. Javam, W. Gibb, S.J. Lye, S.G. Matthews, Effect of oxygen 318 on multidrug resistance in the first trimester human placenta, Placenta 34(9) (2013) 817-23. 
[12] L.M. Tompkins, H. Li, L. Li, C. Lynch, Y. Xie, T. Nakanishi, D.D. Ross, H. Wang, A novel xenobiotic responsive element regulated by aryl hydrocarbon receptor is involved in the induction of BCRP/ABCG2 in LS174T cells, Biochem Pharmacol 80(11) (2010) 1754-61. [13] B. Ebert, A. Seidel, A. Lampen, Identification of BCRP as transporter of benzo[a]pyrene conjugates metabolically formed in Caco-2 cells and its induction by Ah-receptor agonists, 324 Carcinogenesis 26(10) (2005) 1754-63.

[14] H. Wang, L. Zhou, A. Gupta, R.R. Vethanayagam, Y. Zhang, J.D. Unadkat, Q. Mao, Regulation of BCRP/ABCG2 expression by progesterone and 17beta-estradiol in human placental BeWo cells, Am J Physiol Endocrinol Metab 290(5) (2006) E798-807.

[15] P.L. Ee, S. Kamalakaran, D. Tonetti, X. He, D.D. Ross, W.T. Beck, Identification of a novel research 64(4) (2004) 1247-51.

[16] A. Singh, H. Wu, P. Zhang, C. Happel, J. Ma, S. Biswal, Expression of ABCG2 (BCRP) is regulated by Nrf2 in cancer cells that confers side population and chemoresistance phenotype, Molecular cancer therapeutics 9(8) (2010) 2365-76.

[17] Y. Hagiya, T. Adachi, S. Ogura, R. An, A. Tamura, H. Nakagawa, I. Okura, T. Mochizuki, T. Ishikawa, Nrf2-dependent induction of human ABC transporter ABCG2 and heme oxygenase1 in HepG2 cells by photoactivation of porphyrins: biochemical implications for cancer cell response to photodynamic therapy, J Exp Ther Oncol 7(2) (2008) 153-67.

[18] M.T. Hoque, A. Shah, V. More, D.S. Miller, R. Bendayan, In vivo and ex vivo regulation of breast cancer resistant protein (Bcrp) by peroxisome proliferator-activated receptor alpha (Pparalpha) at the blood-brain barrier, J Neurochem 135(6) (2015) 1113-22.

[19] I. Szatmari, G. Vamosi, P. Brazda, B.L. Balint, S. Benko, L. Szeles, V. Jeney, C. OzvegyLaczka, A. Szanto, E. Barta, J. Balla, B. Sarkadi, L. Nagy, Peroxisome proliferator-activated receptor gamma-regulated $\mathrm{ABCG} 2$ expression confers cytoprotection to human dendritic cells, $\mathrm{J}$ Biol Chem 281(33) (2006) 23812-23.

[20] X. Li, Y.Z. Pan, G.M. Seigel, Z.H. Hu, M. Huang, A.M. Yu, Breast cancer resistance protein BCRP/ABCG2 regulatory microRNAs (hsa-miR-328, $-519 \mathrm{c}$ and $-520 \mathrm{~h}$ ) and their differential expression in stem-like ABCG2+ cancer cells, Biochem Pharmacol 81(6) (2011) $783-92$.

[21] F. Wang, X. Xue, J. Wei, Y. An, J. Yao, H. Cai, J. Wu, C. Dai, Z. Qian, Z. Xu, Y. Miao, hsa-miR-520h downregulates ABCG2 in pancreatic cancer cells to inhibit migration, invasion, and side populations, Br J Cancer 103(4) (2010) 567-74.

[22] J. Saito, T. Hirota, S. Furuta, D. Kobayashi, H. Takane, I. Ieiri, Association between DNA methylation in the miR-328 5'-flanking region and inter-individual differences in miR-328 and BCRP expression in human placenta, PLoS One 8(8) (2013) e72906. 

Minekawa, M. Tahara, K. Tasaka, Y. Murata, Induction of glucose transporter 1 expression through hypoxia-inducible factor 1alpha under hypoxic conditions in trophoblast-derived cells, The Journal of endocrinology 183(1) (2004) 145-54.

[24] M.U. Baumann, S. Zamudio, N.P. Illsley, Hypoxic upregulation of glucose transporters in BeWo choriocarcinoma cells is mediated by hypoxia-inducible factor-1, American journal of physiology. Cell physiology 293(1) (2007) C477-85.

[25] S. Zamudio, Y. Wu, F. Ietta, A. Rolfo, A. Cross, T. Wheeler, M. Post, N.P. Illsley, I. Caniggia, Human placental hypoxia-inducible factor-1alpha expression correlates with clinical outcomes in chronic hypoxia in vivo, The American journal of pathology 170(6) (2007) 2171-9.

[26] S. Zamudio, M.U. Baumann, N.P. Illsley, Effects of chronic hypoxia in vivo on the expression of human placental glucose transporters, Placenta 27(1) (2006) 49-55.

367 [27] K.M. Bircsak, V. Gupta, P.Y. Yuen, L. Gorczyca, B.I. Weinberger, A.M. Vetrano, L.M. 368 Aleksunes, Genetic and Dietary Regulation of Glyburide Efflux by the Human Placental Breast 369 Cancer Resistance Protein Transporter, J Pharmacol Exp Ther 357(1) (2016) 103-13.

[28] K.J. Livak, T.D. Schmittgen, Analysis of relative gene expression data using real-time quantitative PCR and the 2(-Delta Delta C(T)) Method, Methods 25(4) (2001) 402-8.

[29] K.M. Bircsak, C.J. Gibson, R.W. Robey, L.M. Aleksunes, Assessment of drug transporter function using fluorescent cell imaging, Current protocols in toxicology / editorial board, Mahin D. Maines 57 (2013) Unit 236.

[30] O. Genbacev, Y. Zhou, J.W. Ludlow, S.J. Fisher, Regulation of human placental development by oxygen tension, Science 277(5332) (1997) 1669-72.

[31] I. Caniggia, J. Winter, S.J. Lye, M. Post, Oxygen and placental development during the first trimester: implications for the pathophysiology of pre-eclampsia, Placenta 21 Suppl A (2000) S25-30.

[32] F. Ietta, Y. Wu, J. Winter, J. Xu, J. Wang, M. Post, I. Caniggia, Dynamic HIF1A regulation

[33] D. Yeboah, M. Sun, J. Kingdom, D. Baczyk, S.J. Lye, S.G. Matthews, W. Gibb, Expression of breast cancer resistance protein (BCRP/ABCG2) in human placenta throughout gestation and at term before and after labor, Canadian journal of physiology and pharmacology 84(12) (2006) $1251-8$.

[34] A.A. Mathias, J. Hitti, J.D. Unadkat, P-glycoprotein and breast cancer resistance protein expression in human placentae of various gestational ages, American journal of physiology. Regulatory, integrative and comparative physiology 289(4) (2005) R963-9.

[35] M. Koritzinsky, M.G. Magagnin, T. van den Beucken, R. Seigneuric, K. Savelkouls, J. Dostie, S. Pyronnet, R.J. Kaufman, S.A. Weppler, J.W. Voncken, P. Lambin, C. Koumenis, N. 
Sonenberg, B.G. Wouters, Gene expression during acute and prolonged hypoxia is regulated by distinct mechanisms of translational control, EMBO J 25(5) (2006) 1114-25.

393 [36] M. Javam, M.C. Audette, M. Iqbal, E. Bloise, W. Gibb, S.G. Matthews, Effect of oxygen on 394 multidrug resistance in term human placenta, Placenta 35(5) (2014) 324-30.

395 [37] G.M. Cheng, K.K. To, Adverse Cell Culture Conditions Mimicking the Tumor 396 Microenvironment Upregulate ABCG2 to Mediate Multidrug Resistance and a More Malignant 397 Phenotype, ISRN Oncol 2012 (2012) 746025.

398 [38] W. Jeong, F.W. Bazer, G. Song, J. Kim, Expression of hypoxia-inducible factor-1 by 399 trophectoderm cells in response to hypoxia and epidermal growth factor, Biochem Biophys Res 400 Commun 469(2) (2016) 176-82.

401 [39] K.P. Tan, B. Wang, M. Yang, P.C. Boutros, J. Macaulay, H. Xu, A.I. Chuang, K. Kosuge, 402 M. Yamamoto, S. Takahashi, A.M. Wu, D.D. Ross, P.A. Harper, S. Ito, Aryl hydrocarbon 403 receptor is a transcriptional activator of the human breast cancer resistance protein 404 (BCRP/ABCG2), Mol Pharmacol 78(2) (2010) 175-85. [40] S.U. Vorrink, P.L. Severson, M.V. Kulak, B.W. Futscher, F.E. Domann, Hypoxia perturbs aryl hydrocarbon receptor signaling and CYP1A1 expression induced by PCB 126 in human skin and liver-derived cell lines, Toxicol Appl Pharmacol 274(3) (2014) 408-16.

[41] S. Khan, S. Liu, M. Stoner, S. Safe, Cobaltous chloride and hypoxia inhibit aryl $410 \quad$ (2007) 28-38.

411 [42] J. Jebbink, G. Veenboer, S. Boussata, R. Keijser, A.E. Kremer, R.O. Elferink, J. van der 412 Post, G. Afink, C. Ris-Stalpers, Total bile acids in the maternal and fetal compartment in relation 413 to placental ABCG2 expression in preeclamptic pregnancies complicated by HELLP syndrome, 414 Biochim Biophys Acta 1852(1) (2015) 131-6.

415 [43] D.A. Evseenko, P. Murthi, J.W. Paxton, G. Reid, B.S. Emerald, K.M. Mohankumar, P.E. 416 Lobie, S.P. Brennecke, B. Kalionis, J.A. Keelan, The ABC transporter BCRP/ABCG2 is a 417 placental survival factor, and its expression is reduced in idiopathic human fetal growth 418 restriction, FASEB J 21(13) (2007) 3592-605. 
A.

HIF-1 $\alpha$

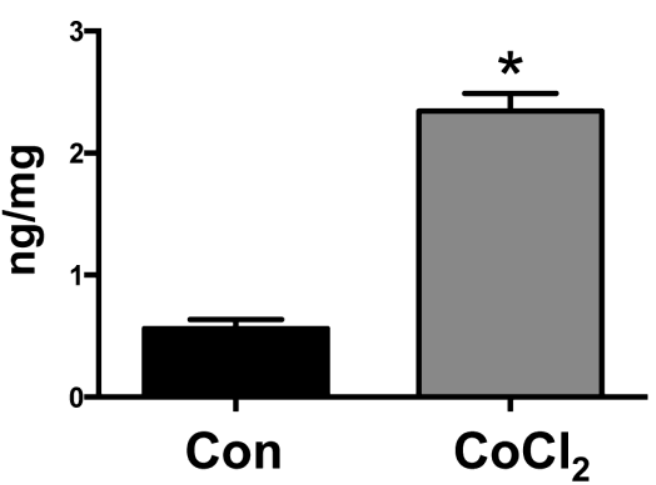

C.

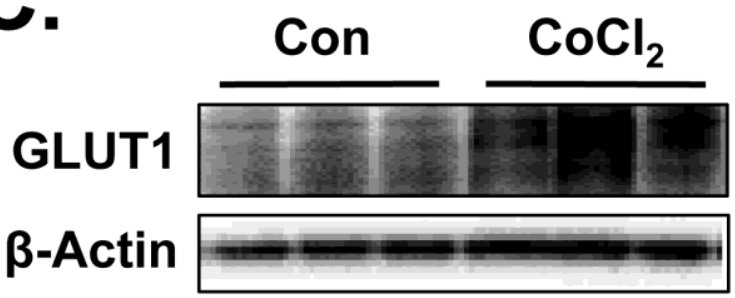

GLUT1

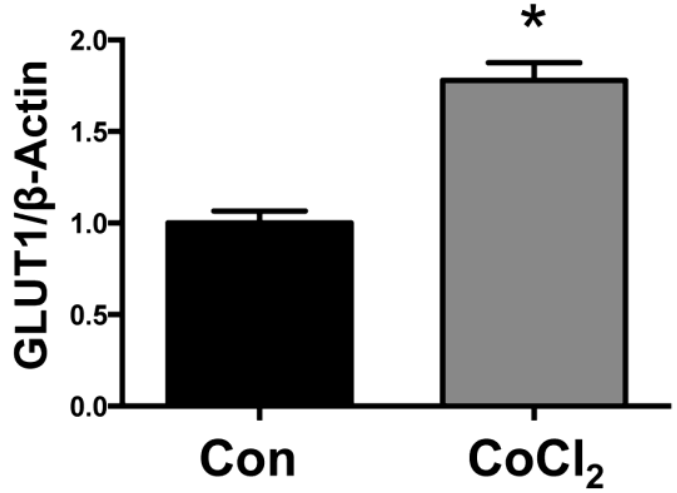

B.

VEGF
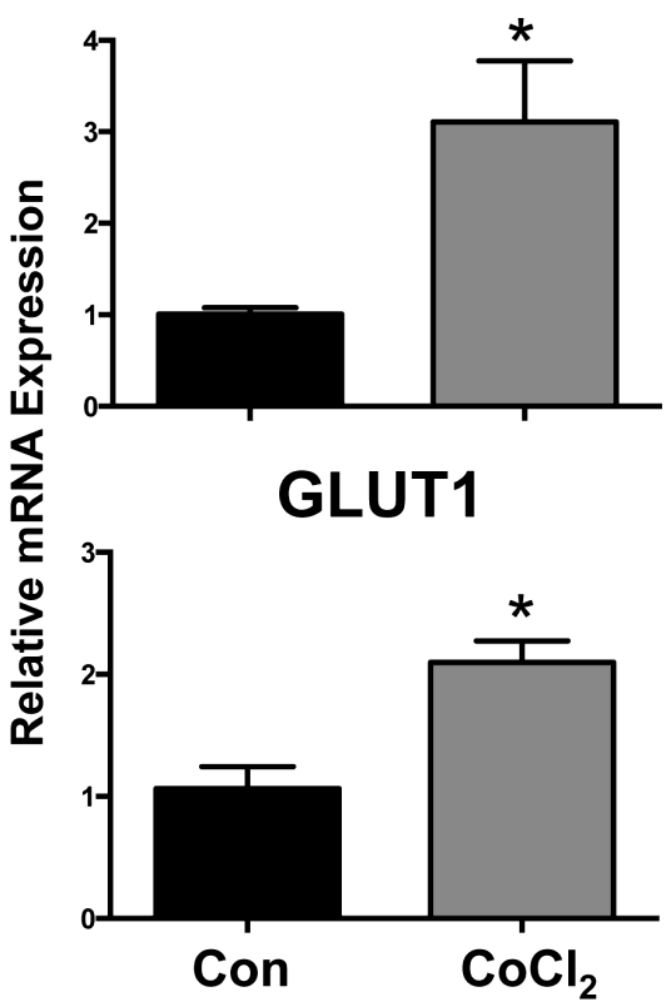

421

FIGURE 1 


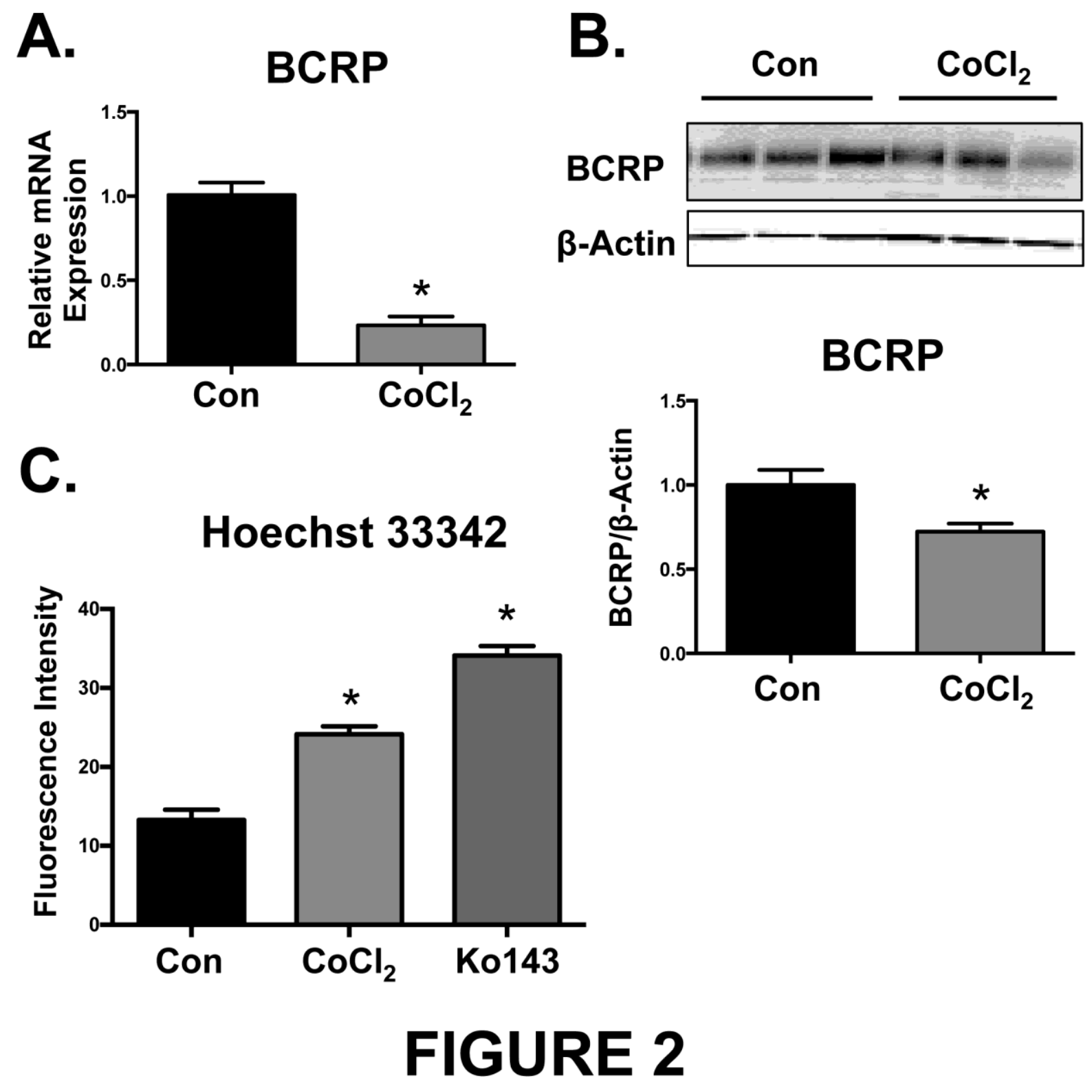

423

424 

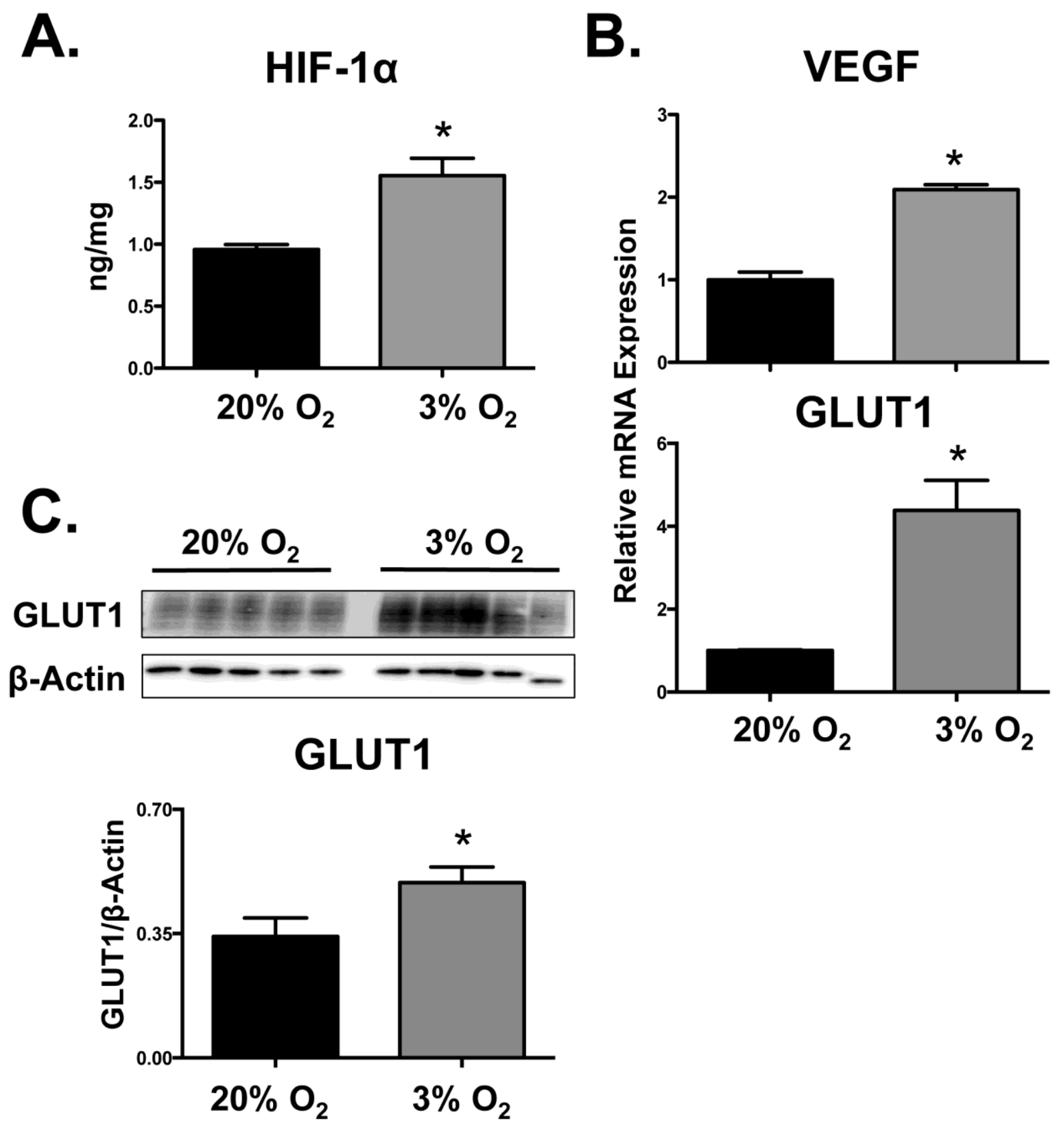

425

FIGURE 3

426 
A.

BCRP

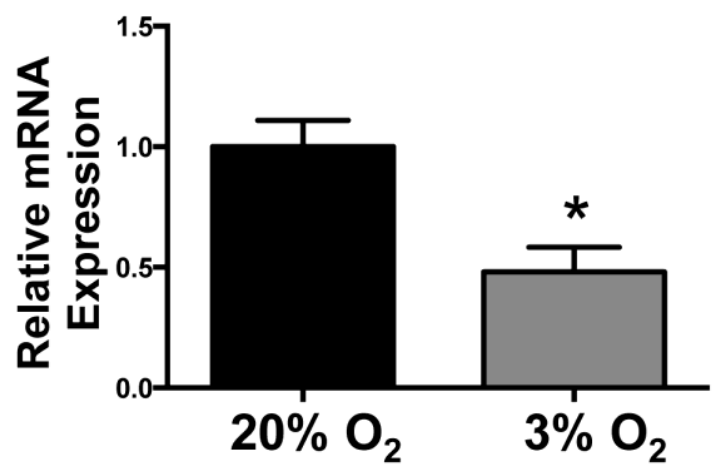

BCRP

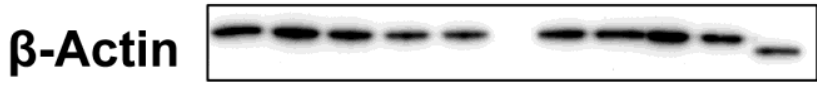

\section{BCRP}

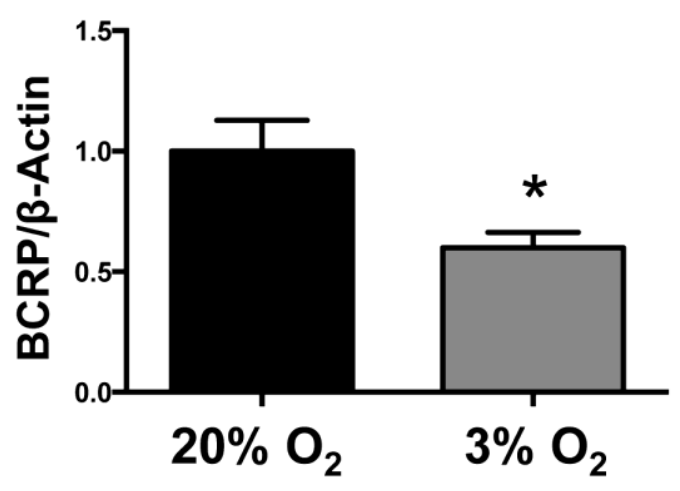

427

Hoechst 33342

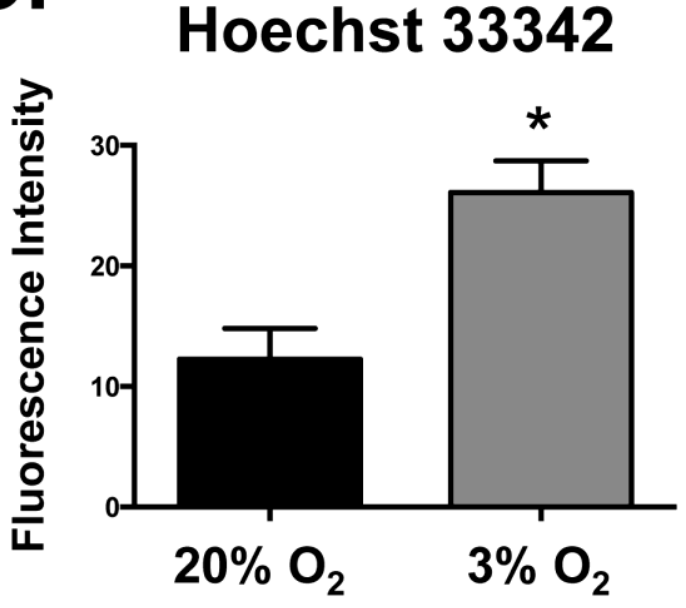

B.

C.

FIGURE 4 

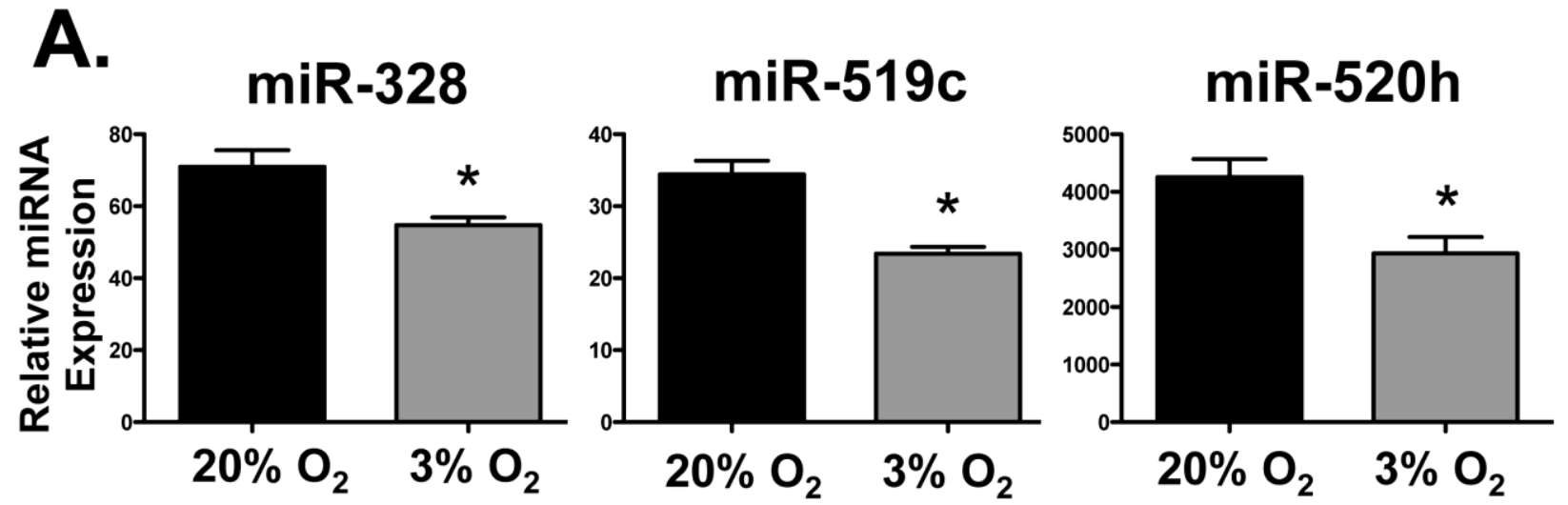

B.
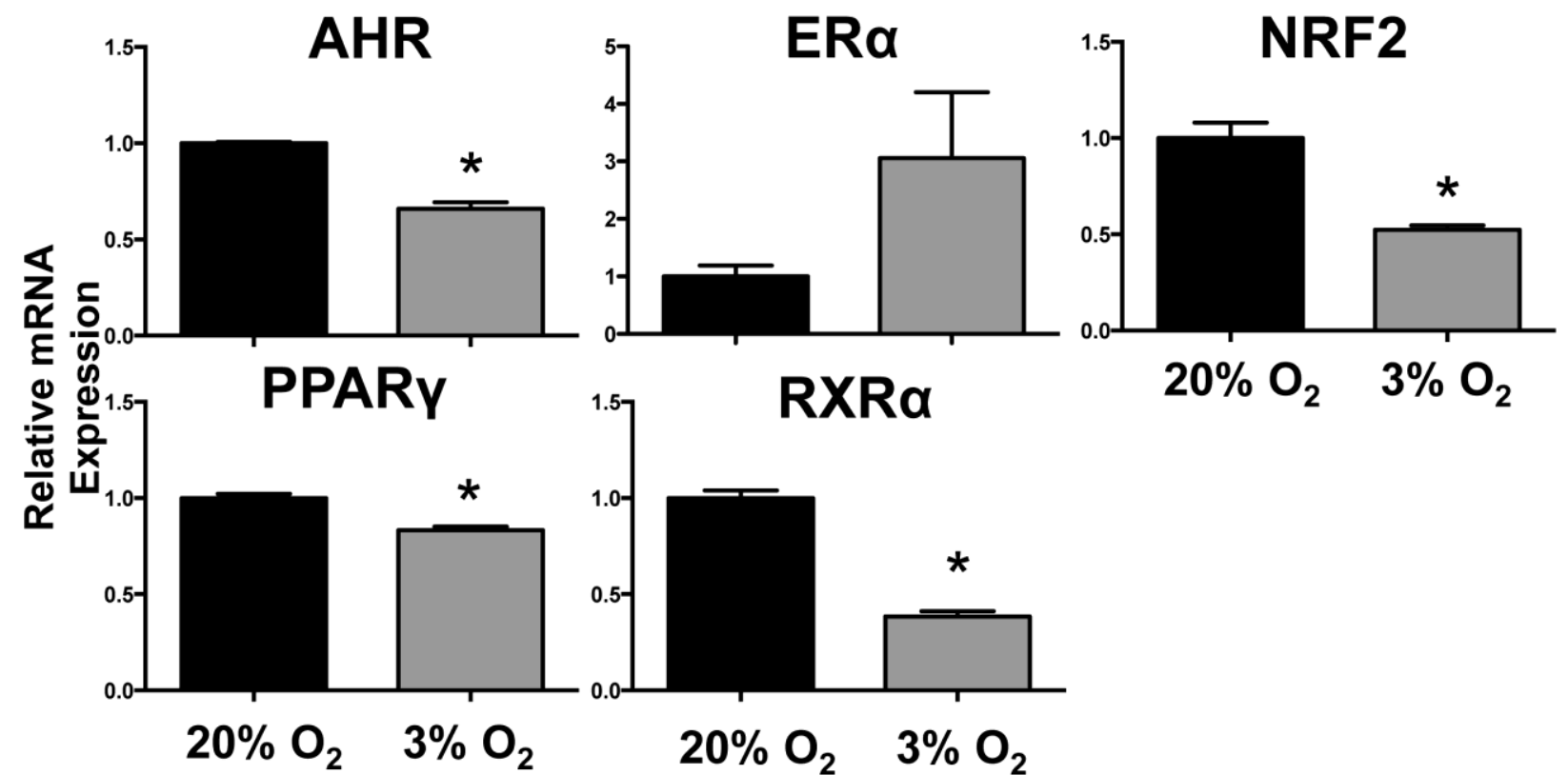

429

430

FIGURE 5 


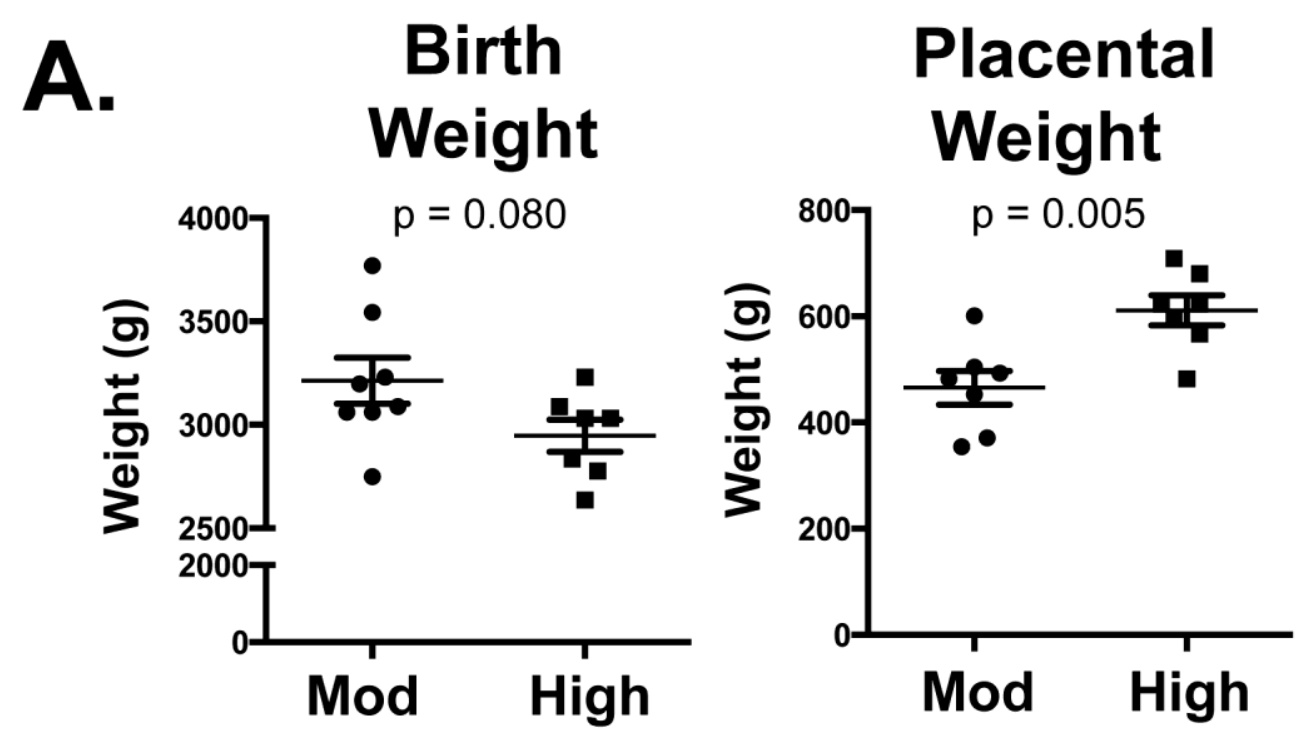

B.

Mod Altitude High Altitude

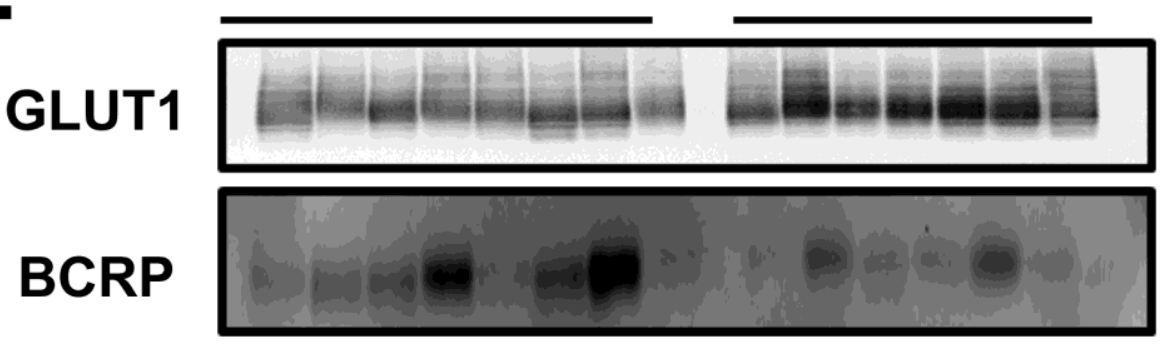

GLUT1
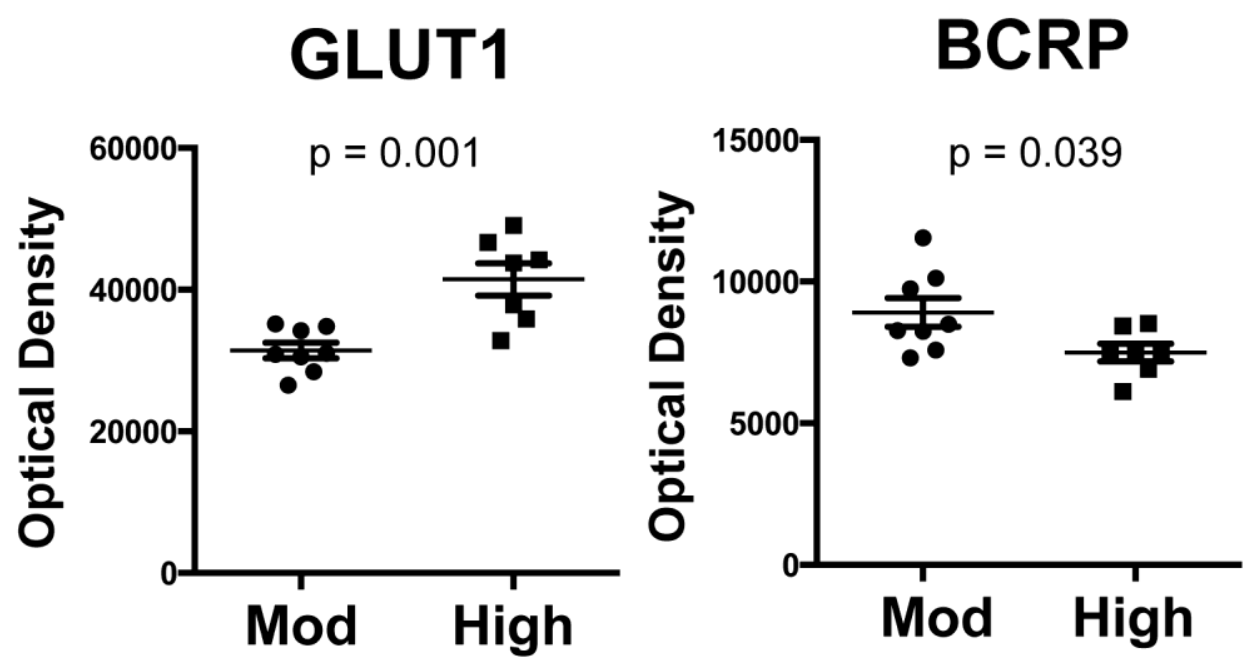

431

FIGURE 6 

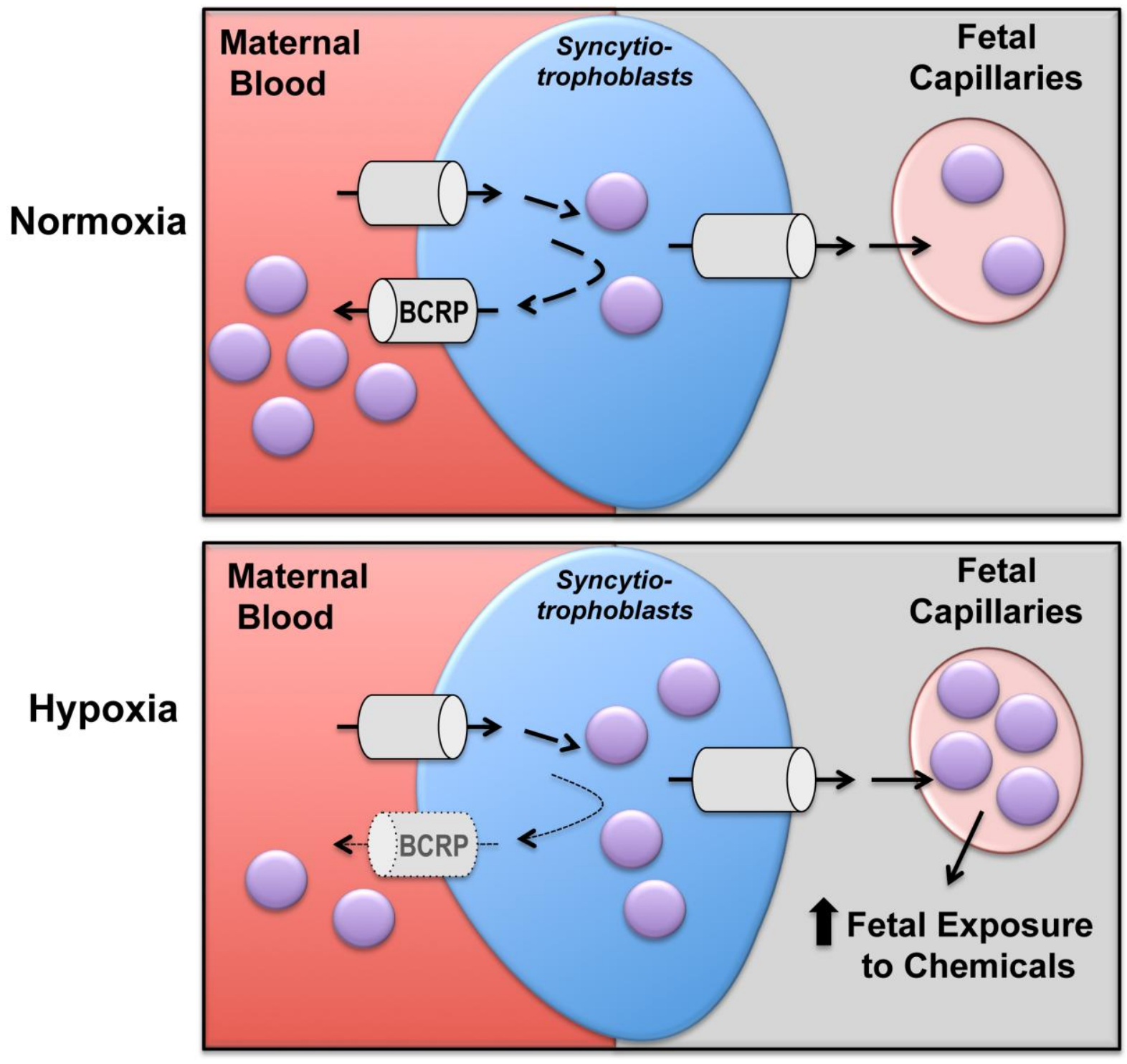